\title{
PHÁT TRIỂN BỀN VŨ̉NG TÀI NGUYÊN NƯỚC LUUU VỰC SÔNG SEREPOK
}

\section{Huỳnh Phú ${ }^{1}$}

Tóm tắt: Tài nguyên nước là yếu tố thiết yếu, có mối quan hệ chặt chẽ với các loại tài nguyên khác nhu đất, không khí và tài nguyên sinh vật, nó quyết định mọi khía cạnh phát triển của địa phưong hay một vùng, lãnh thổ. Hiện nay, vấn đề quản lý và sử dụng bền vũng tài nguyên nước các lưu vực sông là yêu cầu cấp thiết đang được quan tâm rất lớn trên thế giới và Việt Nam. Bài báo trình bày kết quả nghiên cứu bằng nhiều phương pháp khác nhau, phưong pháp lấy mẫu nước, phưong pháp phân tích chất luợng nước, phuoong pháp úng dụng phần mềm tin hoc WQI_Serepok nhằm cung cấp nhanh chóng đầy đủ thông tin về chất lượng nước, giúp cơ quan quản lý ra quyết định phù hơp trong công tác quản lý và phát triển bền vũng nguồn nước lưu vực sông Serepok.

Từ khóa: Phát triển, Phát triển bền vũng, Tài nguyên nước, Lưu vục Sông Serepok, WQI.

Ban Biên tập nhận bài: 12/10/2019 Ngày phản biện xong: 05/12/2019 Ngày đăng bài: 25/12/2019

\section{Mở đầu}

Hiện nay, tài nguyên nước lưu vực sông Serêpốk đang bị khai thác với tốc độ nhanh. Hai ngành sử dụng tài nguyên nước nhiều nhất là thủy điện và thủy lợi. Sự khai thác triệt để của hai ngành này đã dẫn đến mất cân bằng bởi việc sử dụng nước cho các lợi ích khác nhau như giao thông thủy, phát triển du lịch, bảo vệ duy trì hệ thủy sinh, phát triển nuôi thủy sản, xây dựng công trình thủy điện đã khiến cho nguồn nước của sông ở khu vực hạ lưu đang dần bị suy thóai và cạn kiệt tương đối nghiêm trọng trong thời gian mùa kiệt. Tình trạng này đã gây ra những tác động tiêu cực đến chất lượng nước và môi trường dòng sông, nơi đây là địa bàn sinh kế của cả triệu dân cư các tỉnh vùng Tây nguyên $[2,6$, $8,9,10]$.

Nhiều Hội nghị quốc tế đã được tổ chức nhằm đưa ra những thỏa thuận và nguyên tắc làm cơ sở cho phát triển bền vững tài nguyên nước trong tương lai, trước mắt đáp ứng mục tiêu cung cấp nước an toàn trong thế kỷ 21 . Nhiều nước đã xây dựng những định hướng và chính sách cụ thể để phát triển bền vững tài nguyên nước của nước mình [11].

Đóng góp quan trọng trong lĩnh vực này là Hội đồng nước thế giới đã được thành lập và đã đưa ra "Tầm nhìn nước thế giới trong thế kỷ 21 " tại Diễn đàn nước thế giới lần thứ nhất họp tại Marakech, tháng 3/2000. "Tầm nhìn về nước thế giới trong thế kỷ 21 " lại tiếp tục được thảo luận tại Diễn đàn nước thế giới lần thứ hai họp tại Hague, Hà Lan và bản Tuyên bố La Haye về một tầm nhìn về nước, cuộc sống và môi trường đã được Hội nghị Bộ trưởng các nước thông qua với tiêu đề tổng quát là: "một thế giới an ninh về nước trong thế kỷ 21 " gồm 10 thông điệp và 6 chỉ tiêu cần đạt được đều hướng tới phát triển bền vững tài nguyên nước.

Bước vào thế kỷ 21 , các nước trên thế giới đang từng bước đổi mới trong quản lý tài nguyên nước và quản lý lưu vực sông để phát triển tài nguyên nước của nước mình theo hướng bền vững. Nhiều nước trên thế giới đã thu được kết quả khả quan trong nghiên cứu và ứng dụng các kết quả nghiên cứu trong phát triển tài nguyên nước theo hướng bền vững như Pháp, Nhật bản, Úc, Srilanka, Trung quốc, Mỹ.

Nhằm nâng cao năng lực quản lý tài nguyên nước cho các cơ quan quản lý tài nguyên nước cấp Trung ương và địa phương, một dự án về "Nâng cao năng lực đánh giá và quản lý tài nguyên nước Việt Nam” đã được thực hiện tại 7 tỉnh, thành phố là Hà Nam, Nam Định, Ninh 
Bình, Thái Bình, Ninh Thuận, Bình Định và Phú Yên (2008- 2012), bước đầu đã xây dựng cơ sở dữ liệu về tài nguyên nước và nâng cao năng lực quản lý tài nguyên nước của các tỉnh này.

Để tạo các cơ sở khoa học cho việc thực hiện Quản lý tổng hợp tài nguyên nước, quản lý lưu vực sông ở nước ta, nhiều đề tài nghiên cứu khoa học $(\mathrm{NCKH})$ cấp Nhà nước, cấp Bộ về khai thác sử dụng, quản lý và bảo vệ tài nguyên nước, BVMT các lưu vực sông đã được các nhà khoa học của nhiều cơ quan nghiên cứu và các Trường đại học thực hiện. Một trong những nghiên cứu tiêu biểu là Chương trình $\mathrm{NCKH}$ tổng hợp và toàn diện về cân bằng nước trên toàn bộ lãnh thổ Việt Nam - đã được thực hiện trong những năm 1990. Kết quả của chương trình đã góp phần phát triển các phương pháp tính toán, tổng hợp được nhiều quy luật cân bằng nước phục vụ cho phát triển kinh tế của từng tỉnh, từng lưu vực sông trên tất cả các vùng của đất nước.

Nhiều đề tài NCKH cấp Tỉnh, cấp Nhà Nước và cấp Bộ về nghiên cứu xây dựng cơ sở khoa học cho Quản lý tổng hợp tài nguyên nước, Quản lý bảo vệ tài nguyên, môi trường các lưu vực lớn ở nước ta đã được các cơ quan nghiên cứu như các Viện nghiên cứu, Trường đại học về tài nguyên nước của nước ta thực hiện đã tạo ra những cơ sở khoa học ban đầu cho quản lý tài nguyên nước và bảo vệ môi trường lưu vực sông như: trên lưu vực sông Vàm Cỏ Đông có đề tài: (1) "Nghiên cứu các giải pháp tổng hợp bảo vệ môi trường nước sông Vàm Cỏ Đông phục vụ cho phát triển bền vững kinh tế xã hội tỉnh Long An" do GS. TSKH. Lê Huy Bá trường Đại học Công Nghiệp TP. Hồ Chí Minh thực hiện năm 2007, đề tài cấp Tỉnh; (2) "Nghiên cứu khả năng chịu tải môi trường của lưu vực sông Vàm Cỏ phục vụ phát triển Công nghiệp và Kinh tế - xã hội” do GS. TSKH. Lê Huy Bá trường Đại học Công Nghiệp TP. Hồ Chí Minh thực hiên từ năm 2009 - 2011, đề tài cấp Nhà nước; vùng Tây nguyên có các đề tài: (1) "Nghiên cứu xây dựng cơ sở khoa học và đề xuất giải pháp bảo vệ và sử dụng hợp lý tài nguyên nước vùng Tây Nguyên" do trường Đại học Mỏ - Địa chất thực hiện từ 2001 - 2004, đề tài NCKH cấp Nhà nước; (2) "Xây dựng bản đồ phân vùng nguy cơ lũ quét tỉnh Đắk Lắk và biện pháp phòng tránh” do GS. TSKH. Lê Huy Bá trường Đại học Công Nghiệp TP. Hồ Chí Minh thực hiện năm 2010 - 2012, đề tài cấp Tỉnh; trên lưu vực sông Hồng có đề tài "Nghiên cứu cơ sở khoa học và giải pháp công nghệ để phát triển bền vững lưu vực sông Hồng" do Viện Quy hoạch Thủy lợi thực hiện năm 2006, đề tài NCKH cấp Bộ; trên lưu vực sông Ba có đề tài “ Nghiên cứu cơ sở khoa học và kinh nghiệm thực tiến Quản lý tổng hợp tài nguyên nước lưu vực sông Ba" do Đại học Thủy Lợi thực hiện năm 2004, Báo cáo NCKH cấp Bộ; trên lưu vực sông Trà Khúc - sông Vệ có đề tài: "Nghiên cứu mô phỏng dòng chảy lũ lưu vực sông Trà khúc - sông Vệ" do TS. Huỳnh Phú, Trịnh Xuân Mạnh, Nguyễn Hòa Hương thực hiện năm 2013.

Các đề tài nghiên cứu giải pháp khai thác sử dụng hợp lý và bảo vệ tài nguyên, môi trường lưu vực sông: trên lưu vực sông Ba có đề tài "Nghiên cứu giải pháp tổng thể sử dụng hợp lý tài nguyên và $\mathrm{BVMT}$ lưu vực sông $\mathrm{Ba}$ và sông Côn" do Viện Địa lý thực hiện từ năm 2004 2005, Đề tài NCKH cấp Nhà nước KC. 08.25; trên lưu vực sông Lô, sông Chảy có đề tài "Nghiên cứu giải pháp khai thác và sử dụng hợp lý tài nguyên, BVMT và phòng tránh thiên tai lưu vực sông Lô - sông Chảy” do Viện Khí tượng Thủy văn thực hiện từ năm 2004-2005, đề tài NCKH cấp Nhà nước KC.08.27. Các đề tài này bước đầu đã đưa ra giải pháp tổng thể cho khai thác sử dụng và bảo vệ tài nguyên mà trọng tâm là tài nguyên nước theo hướng bền vững; trên lưu vực sông Srêpốk có đề tài: "Đánh giá mối quan hệ của lớp thảm phủ và lưu lượng dòng chảy trên lưu vực sông Srêpốk, Cao nguyên Việt Nam sử dụng GIS và mô hình SWAT" do Nguyễn Thị Ngọc Quyên - Trường Đại học Tây Nguyên, Nguyễn Duy Liêm, Nguyễn Kim Lợi Trường Đại học Nông Lâm TP. Hồ Chí Minh, Bùi Tá Long - Trường Đại học Bách Khoa TP. Hồ Chí Minh thực hiện năm 2010.

Một số đề tài đã nghiên cứu về cơ sở khoa 
học cho khai thác sử dụng và bảo vệ tài nguyên nước, ví dụ: nghiên cứu về ngưỡng khai thác sử dụng nước và dòng chảy môi trường, nghiên cứu giải pháp chống suy thóai cạn kiệt nguồn nước ở hạ lưu các lưu vực sông: đề tài "Nghiên cứu cơ sở khoa học và phương pháp tính toán ngưỡng khai thác sử dụng nước và dòng chảy môi trường lưu vực sông $\mathrm{Ba}$ và sông Trà Khúc" và đề tài "Nghiên cứu xác định dòng chảy môi trường lưu vực sông Hồng - sông Thái Bình, đề xuất các giải pháp duy trì dòng chảy môi trường phù hợp với các yêu cầu phát triển bền vững Tài nguyên nước trên lưu vực sông Hồng - Thái Bình" do Viện Khoa học Thủy lợi thực hiện từ năm 2010 2011; đề tài luận án Tiến sĩ "Khai thác sử dụng hợp lý Tài nguyên đất và nước vùng nhiệt đới”, Phạm Tấn Hà (2006).

Mục tiêu nghiên cứu: đánh giá, dự báo xu thế biến động chất lượng nước trên cơ sở chế độ thủy văn, dòng chảy các nguồn gây ô nhiễm, từ đó đề ra các giải pháp phát triển tài nguyên nước lưu vực sông Serêpốk theo hướng bền vững.

Phạm vi nghiên cứu: Diễn biến nước mặt trên sông Serêpốk tại các xã Tâm Thắng, huyện $\mathrm{Cư}$ Jút tỉnh Đắk Nông, xã Bình Hòa, thị trấn Buôn Trấp thuộc huyện Krông Ana, xã Ea R'Bin thuộc huyện Lắk, xã hòa Phú thuộc TP. Buôn Ma Thuột và các huyện Buôn Đôn, huyện Krông Bông tỉnh Đắk Lắk. Từ 2014 - 2018.

\section{Phương pháp nghiên cứu}

\subsection{Giới thiệu về khu vục nghiên cúu}

Lưu vực Srepok bao gồm: Phần lớn diện tích tỉnh Đắk Lắk $(10.400$ km²), một phần diện tích tỉnh Đắk Nông $(3.600$ km²), một phần diện tích tỉnh Gia Lai $\left(2.900 \mathrm{~km}^{2}\right)$ Một phần nhỏ diện tích tỉnh Lâm Đồng $\left(1.300 \mathrm{~km}^{2}\right)$. Tổng diện tích lưu vực trong lãnh thổ Việt Nam là 18.264 km² [2] (Hình 1).

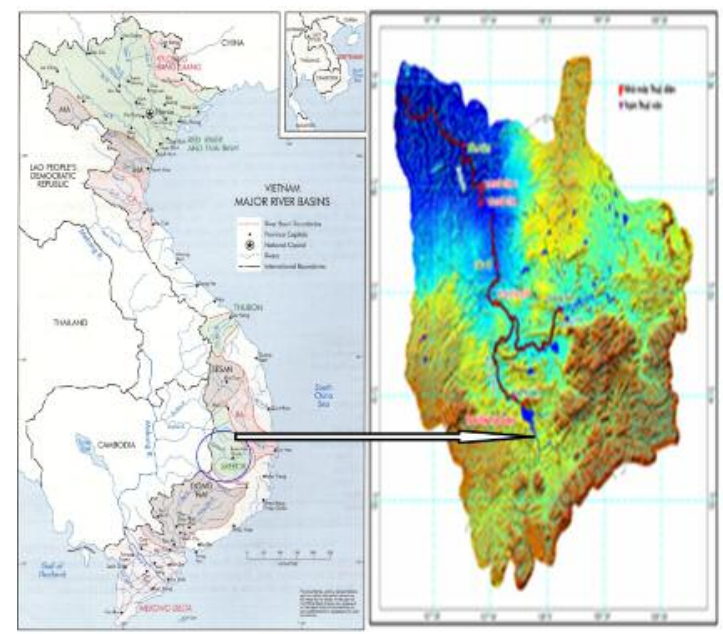

Hình 1. Mạng lưới sông Serepok

\subsubsection{Mạng luới sông Serepok}

Sông Srepok là chi lưu cấp 1 của sông Mê Kông. Trong địa phận tỉnh Đắk Lắk, Đắk Nông diện tích lưu vực của dòng chính là $4.200 \mathrm{~km}^{2}$ với chiều dài sông $125 \mathrm{~km}$.

Đoạn này lòng sông tương đối dốc, chảy từ độ cao 400 m nhập lưu xuống cao độ 150 m ở biên giới Cam Pu Chia. Sông Serepok do 2 nhánh sông Krông Nô và Krông Ana hợp thành [6].

Bảng 1. Đặc trung hình thái sông ngòi luu vục Serepok [6]

\begin{tabular}{lllllll}
\hline \multicolumn{1}{c}{ Sông } & $\mathrm{F}\left(\mathrm{km}^{2}\right)$ & $\begin{array}{c}\text { Chiều dài } \\
\text { sông L }(\mathrm{km})\end{array}$ & $\begin{array}{c}\text { Chiều dài } \\
\text { lưu vực } \\
(\mathrm{km})\end{array}$ & $\begin{array}{c}\text { Cao độ bq } \\
\text { lưu vực }\end{array}$ & $\begin{array}{c}\text { Độ dốc lòng } \\
(\% \mathrm{o})\end{array}$ & $\begin{array}{c}\text { Mật độ lưới } \\
\text { sông }\end{array}$ \\
\hline Serepok & 18264 & 315 & 183 & 570 & 2.3 & 0,55 \\
Krông Ana & 3960 & 215 & 97 & 676 & 2,3 & 0,55 \\
Krong Pach & 690 & 74 & 53 & 752 & 5,8 & 0,69 \\
Krong Buk & 478 & 13 & 58 & 590 & 5,5 & 0,56 \\
Krông Bông & 788 & 73 & 56 & 950 & 9,2 & 0,5 \\
Krông Nô & 3920 & 156 & 125 & 917 & 6,8 & 0,86 \\
Ia Hleo & 4760 & 128 & 80 & 336 & 6.1 & 0,35 \\
Ia Soup & 994 & 104 & 62 & 366 & 6.0 & 0,4 \\
Ia Đrăng & 977 & 78 & 60 & 391 & 5.9 & 0,44 \\
\hline
\end{tabular}




\subsubsection{Phát triển bền vĩng tài nguyên nước} lư vưc sông

Phát triển bền vững (PTBV) đòi hỏi các tài nguyên phải được sử dụng một cách hợp lý, hiệu quả với những phương thức khôn khéo, thông minh để tài nguyên không bị suy thoái và có thể sử dụng lâu dài. PTBV tài nguyên nước trên thế giới tập trung thống kê chất lượng và trữ lượng của tài nguyên, chủ yếu là tài nguyên nước tái tạo. Tài nguyên nước tái tạo là lượng dòng chảy trung bình nhiều năm trong sông và lượng nước bổ sung từ mưa cho tầng ngậm nước.

2.1.3. Phát triển bền vũng tài nguyên nước lưu vục sông Serepok

Phát triển tài nguyên nước (PTTNN) theo hướng bền vững hiểu theo khái niệm của PTBV sẽ là khai thác sử dụng nước của các LVS phải mang lại hiệu quả kinh tế cao góp phần cho phát triển xă hội, nhưng vẫn duy trì được khả năng tái tạo và bảo vệ được $\mathrm{TNN}$ cho các thế hệ mai sau sử dụng. Theo Daniel P (1999): "PTBVTNN là sự phát triển được thiết kế và được quản lý nhằm đáp ứng đầy đủ mục tiêu của xã hội hiện tại và tương lai, trong khi đó vẫn duy trì được tính toàn vẹn về sinh thái, môi trường và thủy văn của chúng", [6,7,8,9].

Việc khai thác triệt để của hai ngành này đã dẫn đến mất cân bằng bởi việc sử dụng nước cho các lợi ích khác nhau như giao thông thủy, phát triển du lịch, bảo vệ duy trì hệ thủy sinh, phát triển nuôi thủy sản, xây dựng công trình thủy điện đã khiến cho nguồn nước của sông ở khu vực hạ lưu đang dần bị suy thoái và cạn kiệt tương đối nghiêm trọng trong thời gian mùa kiệt.

Do địa hình lưu vực phức tạp, thấp dần từ Đông Nam sang Tây Bắc nên dòng sông phải hứng chất thải từ nhiều khu công nghiệp như Hòa Phú (Đắk Lắk), Tâm Thắng (Đắk Nông)...PTBVTNN lưu vực sông Serepok là sự phát triển được thiết kế và được quản lý nhằm đáp ứng đầy đủ mục tiêu xã hội của các tỉnh Đắk lắk, Đắk nông, Gia lai, Lâm đồng, hiện tại và tương lai, đảm bảo duy trì được tính toàn vẹn về sinh thái, môi trường và thủy văn của lưu vực sông.

\subsection{Phương pháp lấy mẫu và bảo quản mẫu}

Nghiên cứu thực hiện lấy mẫu nước mặt theo TCVN 5996:1995 "Chất lượng nước, lấy mẫu Hướng dẫn lấy mẫu ở sông và suối”. Các mẫu nước mặt được lấy tại các vị trí như sau: mẫu trên nhánh sông Krông Nô; nhánh sông Krông Ana, mẫu giao giữa Krông Nô và Krông Ana và các mẫu trên dòng chính sông Srepok. Các vị trí lấy mẫu trình bày trong bảng 2 và 3 .

\subsection{Phương pháp phân tích}

Đây là một phương pháp định lượng trong việc xác định chất lượng nước theo các chỉ tiêu được quy định trong tiêu chuẩn QCVN 08:2008/BTNMT. Mẫu nước phân tích theo các chỉ tiêu tại phòng phân tích của Viện Địa lý Sinh thái và Môi trường. Quy trình phân tích các chỉ tiêu môi trường được tiến hành theo tiêu chuẩn quốc tế (Standard Methods for the Exammination of Water and Wastewater, 2005).

\subsection{Phưong pháp lập trình tin học}

Sử dụng ngôn ngữ lập trình Visual Basic thành lập phần mềm Serepok_WQI, tính toán chỉ số chất lượng nước (WQI).

Nhập các thông số DO, Nhiệt độ, BOD5, COD, N-NH4, TSS... Click vào Tính toán ta có được chỉ số WQI và Click vào Hiển thị thì trên bản đồ sẽ xuất hiện các màu khác nhau thể hiện mức độ ô nhiễm [6].

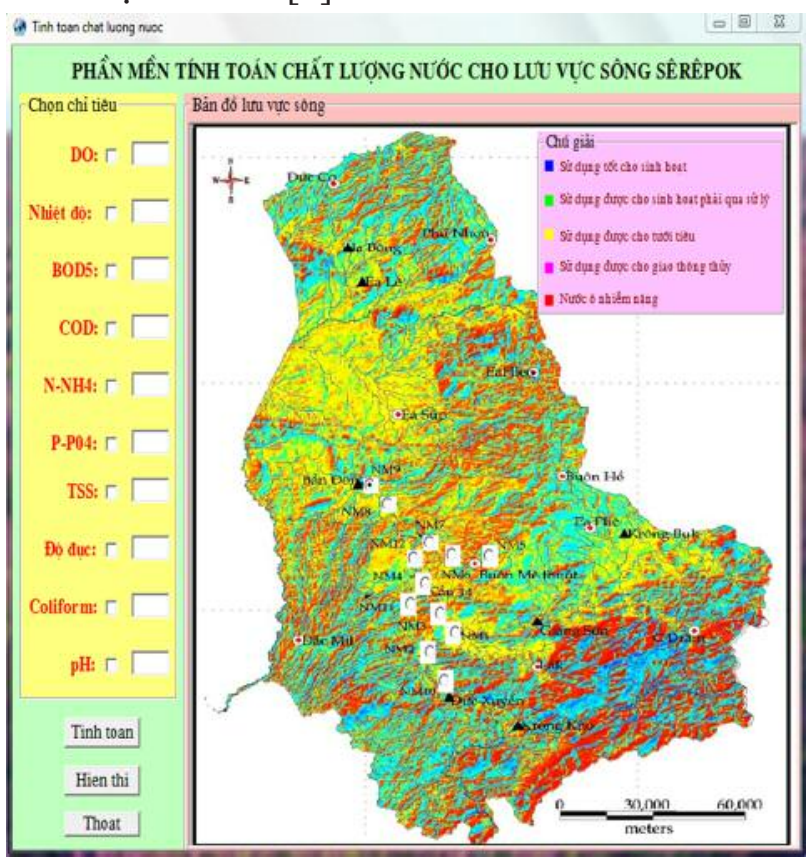

Hình 2. Cửa sổ phần mềm tính toán chỉ số WQI cho lưu vục sông Serepok 
Bảng 2. Các vị trí quan trắc qua các năm trên lưu vục sông Serepok [6]

\begin{tabular}{|c|c|c|c|c|}
\hline \multirow{2}{*}{ STT } & \multirow{2}{*}{ Ký hiệu } & \multirow[t]{2}{*}{ Vị trí quan trắc } & \multicolumn{2}{|c|}{ Tọa độ } \\
\hline & & & Kinh độ & Vĩ độ \\
\hline 1 & NM1' & Cầu 14 sông Serepok & 107.92 & 12.62 \\
\hline 2 & NM2’ & Trạm Thuỷ văn bản Đôn & 107.75 & 12.91 \\
\hline 3 & NM3' & Cầu EaNhol & 107.89 & 12.55 \\
\hline 4 & NM4' & Mạch Ecôtam & 107.90 & 12.68 \\
\hline 5 & NM5 & Km4 suối EaNao & 107.92 & 12.33 \\
\hline 6 & NM6' & Cầu Giang Sơn & 108.12 & 12.42 \\
\hline 7 & NM7' & Cầu Krông Nô & 108.18 & 12.51 \\
\hline
\end{tabular}

Bảng 3. Các vị trí lấy mẫu bổ sung trên dòng chính ở lưu vực sông Serepok [6]

\begin{tabular}{|c|c|c|c|c|}
\hline \multirow[b]{2}{*}{ STT } & \multirow[b]{2}{*}{ Ký hiệu mẫu } & \multirow[b]{2}{*}{ Vị trí lấy mẫu } & \multicolumn{2}{|c|}{ Tọa độ } \\
\hline & & & Kinh độ & Vĩ độ \\
\hline 1 & NM1 & $\begin{array}{l}\text { Nước mặt hạ nguồn sông Krông Nô trước khi nhập } \\
\text { thành sông Serepok }\end{array}$ & 108.00 & 12.47 \\
\hline 2 & NM2 & $\begin{array}{l}\text { Nước mặt hạ nguồn sông Krông Ana trước khi nhập } \\
\text { thành sông Serepok }\end{array}$ & 107.93 & 12.42 \\
\hline 3 & NM3 & $\begin{array}{l}\text { Nước mặt tại vị trí cách điểm hợp lưu của } 2 \text { sông } \\
\text { Krông Ana và sông Krông Nô khoảng cách } 2 \text { km. }\end{array}$ & 107.96 & 12.51 \\
\hline 4 & NM4 & Trên dòng chính Serepok tại KCN Hòa Phú. & 107.90 & 12.54 \\
\hline 5 & NM5 & $\begin{array}{l}\text { Suôi Ea Nao giao với quốc lộ } 26 \text { - đường Nguyê̂n } \\
\text { Văn Cừ. }\end{array}$ & 108.09 & 12.69 \\
\hline 6 & NM6 & Suối Đốc Học giao đường Hoàng Hoa Thám. & 108.00 & 12.68 \\
\hline 7 & NM7 & $\begin{array}{l}\text { Suối Ea Druêch vị trí điểm xả nước thải sinh hoạt } \\
\text { thành phố Buôn Ma Thuột } 200 \mathrm{~m} \text {. }\end{array}$ & 107.94 & 12.72 \\
\hline 8 & NM8 & Tại vị trí sau Thủy điện Serepok 4. & 107.84 & 12.84 \\
\hline 9 & NM9 & $\begin{array}{l}\text { Tại sông Serepok vị trí khu du lịch Biệt Điện - } \\
\text { Vườn Quốc ga Yok Dôn (Bến Tha Luống). }\end{array}$ & 107.83 & 12.96 \\
\hline
\end{tabular}

\section{Kết quả và thảo luận}

\subsection{Kết quả quan trắc chất lự̛ng nước}

Kết quả quan trắc chất lượng nước mặt (CLNM), từ năm 2014 tới năm 2018 tại các vị trí Cầu 14 sông Serêpốk, trạm thủy văn Bản Đôn, cầu Eanhol, Mạch EcôTam, Km4 suối EaNao, Cầu giang Sơn, cầu Krông Nô. Ngoài ra, nhóm nghiên cứu còn kết hợp lấy mẫu thực tế để phân tích bổ sung tại 9 vị trí trong bảng. Các số liệu được số hóa vị trí lấy mẫu và lập bản đồ lấy mẫu phân tích (Bảng 3).

\section{2. Đánh giá chất lương nước theo số liệu quan trắc}

Đánh giá chất lượng nước mặt (CLNM) tại các vị trí quan trắc qua các năm trên lưu vực sông Serepok (Bảng 2 và Bảng 3 ) theo $\mathrm{QCVN}$ 08: 2008/ BTNMT, từ các số liệu của nhóm nghiên cứu thực hiện và các số liệu của Sở Tài nguyên và môi trường tỉnh Đắk Lắk, Đài Khí tượng Thủy văn khu vực Tây Nguyên để đánh giá các chỉ tiêu chất lượng nước tiêu biểu BOD5, COD, DO, $\mathrm{NO}_{3}{ }^{-}, \mathrm{PO}_{4}{ }^{3-}, \mathrm{NH}_{4}{ }^{+}$, Coliform tại 7 vị trí trên sông chính: Cầu 14 sông Serepok; Trạm thủy văn Buôn Đôn; Cầu Eanhol; Mạch EaCôTam; Km4 suối EaNao; Cầu Giang Sơn; Cầu Krông Nô.

Chất lượng nước mặt tại thành phố Buôn Mê Thuột và vùng phụ cận có dấu hiệu ô nhiễm, có nơi vượt 2,7 lần như suối EaNao, COD vượt 3,9 lần như cầu Krông Nô. Hàm lượng chất rắn lơ lửng trong nước vào mùa khô giao động từ 3 $14.5 \mathrm{mg} / 1$. Vào mùa mưa hàm lượng chất rắn lơ lửng tại cầu EaNhol gấp 2,8 lần tiêu chuẩn cho phép. Đặc biệt năm 2014 tại cầu Krong Nô gấp 
4 lần. Nhìn chung, vào mùa mưa ở một số vị trí hàm lượng chất rắn lơ lửng cao hơn tiêu chuẩn cho phép nhiều lần.

Các chất dinh dưỡng: NO3-, NH4+ trong nguồn nước làm tăng sinh khối (rong, tảo) trong hệ sinh thái nước và là nguyên nhân dẫn đến sự suy giảm chất lượng nước. Nguồn chất dinh dưỡng vào nước là nguồn phân bón (đạm, lân) trong canh tác nông, lâm nghiệp, chất bài tiết của người, gia súc và một số loại chất thải công nghiệp (chế biến thực phẩm). Đặc biệt vào mùa mưa do nước mưa rửa trôi cuốn theo lượng phân bón từ hoạt động Nông nghiệp làm nồng độ của NH4+ và PO43- tăng so với các mùa khác trong năm. Hàm lượng các chất dinh dưỡng diễn biến tăng theo năm nhưng vẫn nằm trong giới hạn cho phép theo cột A2 QCVN 08:2008/BTNMT.

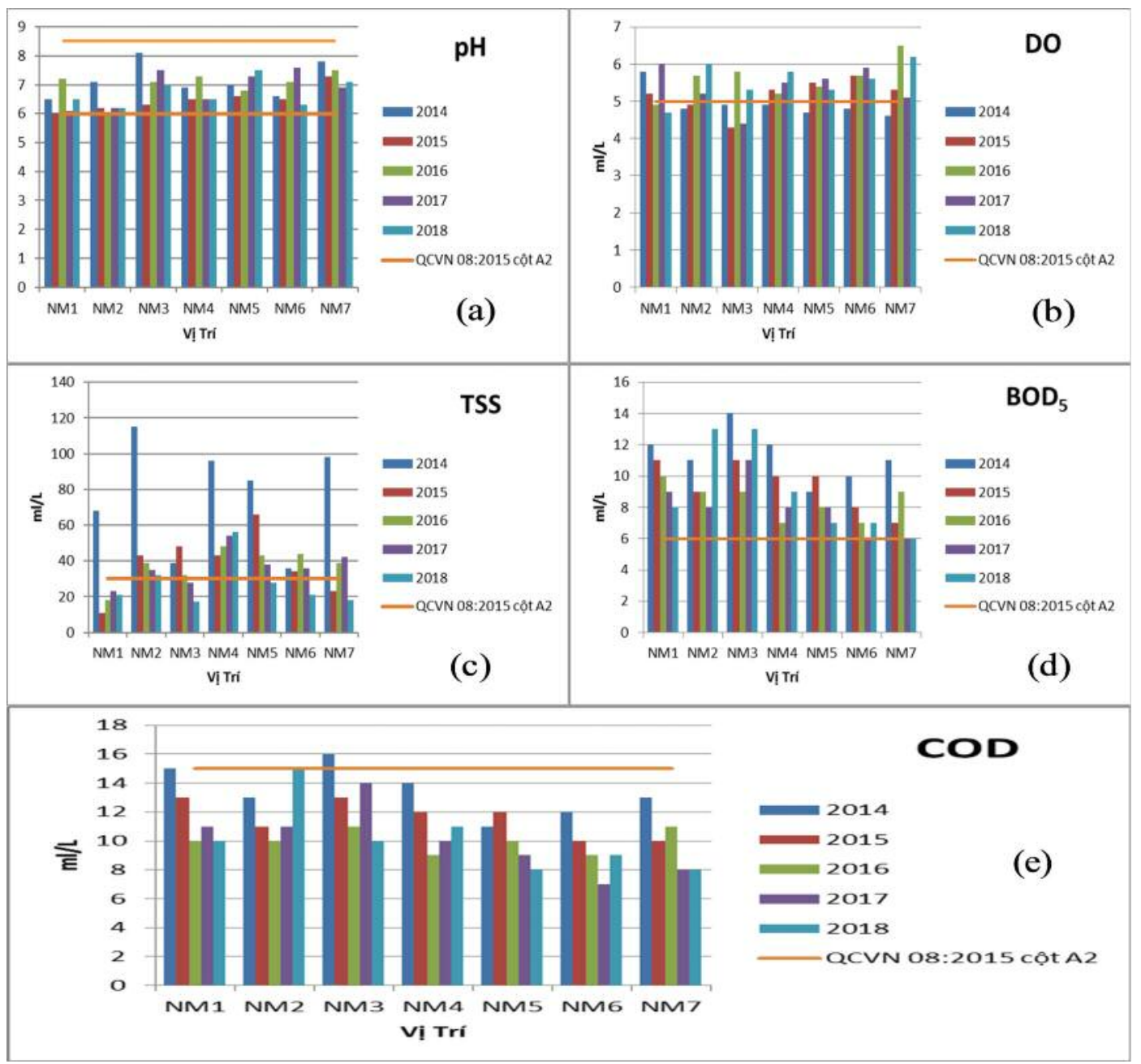

Hình 3. Biểu đồ thể hiện diễn biến nồng độ $\mathrm{pH}, \mathrm{DO}$, TSS, BOD5, COD trên lưu vục sông Serepok

Tại các vị trí quan trắc trên sông Srepok kết quả phân tích DO trong khoảng thời gian từ năm 2014-2018 có xu hướng tăng, riêng năm 2016 tại các điểm quan trắc EaNhol, Ecôtam, suối EaNao chưa đạt tiêu chuẩn. Hàm lượng $\mathrm{COD}$ và $\mathrm{BOD}$ tại các điểm khảo sát, nhìn chung, các kết quả phân tích có hàm lượng vượt giới hạn cho phép theo tiêu chuẩn loại A2.
Chất lượng nước mặt tại thành phố Buôn Mê Thuột và vùng phụ cận có dấu hiệu ô nhiễm, có nơi vượt 2,7 lần như suối EaNao, COD vượt 3,9 lần như cầu Krông Nô. Hàm lượng chất rắn lơ lửng trong nước vào mùa khô giao động từ 3 $14,5 \mathrm{mg} / \mathrm{l}$. Vào mùa mưa hàm lượng chất rắn lơ lửng tại cầu EaNhol gấp 2,8 lần tiêu chuẩn cho phép. Đặc biệt năm 2014 tại cầu Krong Nô gấp 
4 lần. Nhìn chung, vào mùa mưa ở một số vị trí hàm lượng chất rắn lơ lửng cao hơn tiêu chuẩn cho phép nhiều lần.

Các chất dinh dưỡng: $\mathrm{NO}_{3}{ }^{-}, \mathrm{NH}_{4}{ }^{+}$trong nguồn nước làm tăng sinh khối (rong, tảo) trong hệ sinh thái nước và là nguyên nhân dẫn đến sự suy giảm chất lượng nước. Nguồn chất dinh dưỡng vào nước là nguồn phân bón (đạm, lân) trong canh tác nông, lâm nghiệp, chất bài tiết của người, gia súc và một số loại chất thải công nghiệp (chế biến thực phẩm). Đặc biệt vào mùa mưa do nước mưa rửa trôi cuốn theo lượng phân bón từ hoạt động Nông nghiệp làm nồng độ của $\mathrm{NH}_{4}{ }^{+}$và $\mathrm{PO}_{4}{ }^{3-}$ tăng so với các mùa khác trong năm. Hàm lượng các chất dinh dưỡng diễn biến tăng theo năm nhưng vẫn nằm trong giới hạn cho phép theo cột A2 QCVN 08:2008/BTNMT.

Qua các kết quả quan trắc các chỉ số vi sinh đều nằm trong giới hạn cho phép. Tuy nhiên, có một số vùng đã bị ô nhiễm. Cụ thể: tại Km4 suối EaNao tổng Coliform cao hơn 6,5 lần so với cột A2, QCVN 08:2008/BTNMT, tại vị trí này ô nhiễm rất nặng do nước thải chợ và nước thải sinh hoạt của người dân chưa qua xử lý xuống suối, cần phải có biện pháp xử lý kịp thời. E. Coli tại các điểm đo hầu hết đều cao hơn nhiều lần so với tiêu chuẩn loại $\mathrm{A} 2$ chỉ trừ trạm thủy văn Bản Đôn và Mạch Ecôtam vẫn nằm trong giới hạn tiêu chuẩn cho phép. pH tại vị trí suối Ea Đruêh cách điểm xả nước thải của nhà máy XLNT sinh hoạt TP. Buôn Ma Thuột 200m về phía hạ lưu có giá trị tương đối cao, đặc biệt vào mùa mưa $\mathrm{pH}$ lên đến 8 . Tại các điểm khảo sát $\mathrm{pH}$ đều trong giới hạn cho phép theo QCVN 08:2008/BTNMT cột A2.

Hình $3 \mathrm{~d}$ biểu thị diễn biến thông số BOD5 theo không gian và thời gian của các mẫu phân tích. Kết quả cho thấy $\mathrm{BOD}_{5}$ có xu thế giảm dần ở một số vị trí như: ở thượng nguồn của sông Krông ANa, Krông Nô, sau khu công nghiệp Hòa Phú, suối Ea Đruêh cách điểm xả nước thải của nhà máy XLNT sinh hoạt Tp Buôn Ma Thuột $200 \mathrm{~m}$ về phía hạ lưu đều vượt quy chuẩn
QCVN 08:2008/BTNMT từ 0,9 đến 5,2 lần.

Hình $3 \mathrm{e}$ biểu thị diễn biến thông số COD theo không gian và thời gian của các mẫu phân tích. Kết quả cho thấy COD có xu thế giảm dần, hầu hết vào mùa mưa và lúc giao mùa hàm lượng COD tại các vị trí lấy mẫu đều vượt quy chuẩn QCVN 08:2008/BTNMT từ 0,6 đến 4,5 lần.

Ở hạ lưu sông Serepok, đặc biệt là tại vị trí sau khu công nghiệp Hòa Phú, suối Ea Đruêh cách điểm xả nước thải của nhà máy XLNT sinh hoạt Tp Buôn Ma Thuột $200 \mathrm{~m}$ về phía hạ lưu và của điểm tập trung đông dân cư là TP. Đoạn từ hạ nguồn sông Krông Nô, Krông ANa trước khi nhập thành sông Serepok (từ vị trí 1 đến vị trí 3): nếu so với cột $\mathrm{A} 2$ thì nước sông đã bị ô nhiễm nhưng mức độ ô nhiễm còn thấp. Đoạn sông chảy qua thành phố Buôn Ma Thuột (từ sau vị trí 3 đến vị trí 9) chất lượng nước bị suy giảm nhanh chóng và ô nhiễm hữu cơ, ô nhiễm sinh học đã rất rõ rệt với thông số $\mathrm{BOD}_{5}$ và $\mathrm{COD}$ cao hơn tiêu chuẩn cho phép trong cột $\mathrm{A} 2, \mathrm{QCVN}$ 08:2008 từ 0,5 đến 5 lần.

\section{3. Đánh giá chất lựng nước theo chỉ số chất lựng nước WQI}

Qua các năm từ 2014 - 2018, chất lượng nước có sự suy giảm, đặc biệt có 3 vị trí có màu đỏ tức là bị ô nhiễm nặng, cụ thể tại vị trí: Km4 suối EaNao tiếp nhận nước thải sinh hoạt TP. Buôn Ma Thuật.

Nước sông có màu vàng tại các vị trí: Cầu 14 sông Serepok, cầu EaNhol, Cầu Krông Nô cho thấy nước có thể sử dụng cho mục đích tưới tiêu. Tại vị trí Nước sông có màu vàng tại các vị trí: đoạn sông hạ nguồn sông Krông Nô trước khi nhập thành sông Serepok, suối Ea Druêch vị trí cách điểm xả nước thải của nhà máy xử lý nước thải sinh hoạt thành phố Buôn Ma Thuột 200 m, tại vị trí sau Thủy điện Srepok 4 và tại sông Serepok vị trí phía sau khu du lịch Biệt Điện - Vườn Quốc ga Yok Dôn (Bến Tha Luống).

Kết quả đánh giá theo chỉ số chất lượng nước WQI được thể hiện lần lượt tại hình 4, 5, 6. 


\section{BÀI BÁO KHOA HỌC}

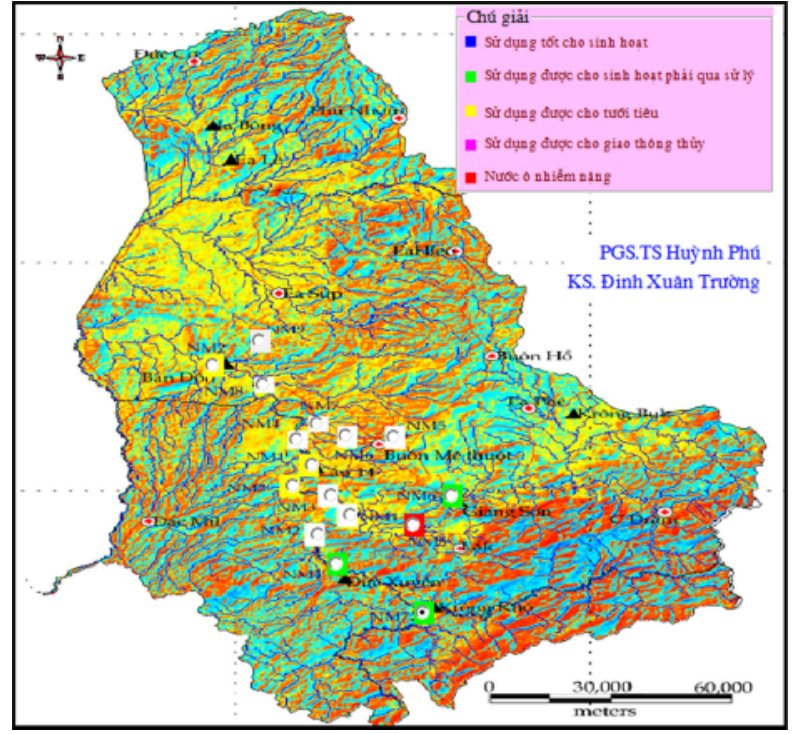

Hình 4. Bản đồ CLN năm 2016 tại vị trí quan trắc qua các năm trên sông Serepok

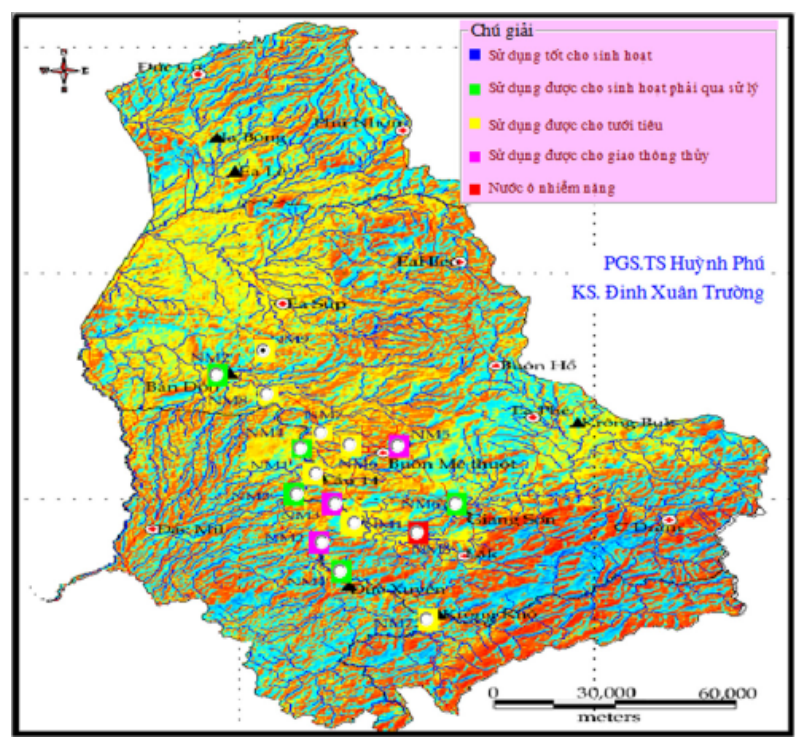

Hình 5. Bản đồ CLN năm 2017 tại vị trí quan trắc và trị vị trí quan trắc bổ sung trên sông Serepok

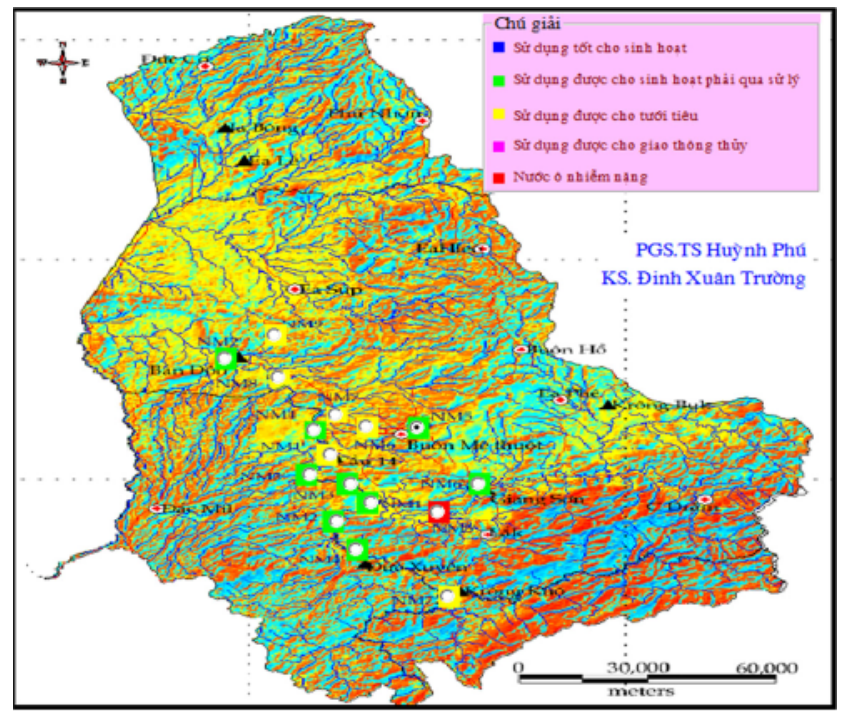

Hình 6. Bản đồ CLN năm 2018 tại vị trí quan trắc và trị vị trí quan trắc bổ sung trên sông Serepok

Ô nhiễm nước lưu vực sông Serepok dựa vào chỉ số WQI đã nêu ở trên phù hợp với kết quả đánh giá chất lượng nước và ô nhiễm nước theo số liệu thực đo. Nhu cầu nước cho các tiểu lưu vực Lắk, Buôn Trấp, Quảng Phú - Đức khoảng từ $0,43-1,54 \mathrm{mg} / 1$, cao nhất và vượt QCVN08:2008/BTNMT- A1 là 1,5 lần quy định $<1 \mathrm{mg} / 1$. Hàm lượng Fe tại suối Ea Nhuôl từ $0,17-1,93 \mathrm{mg} / 1, \quad$ cao và vượt QCVN08:2008/BTNMT- A1 3,9 lần.

Ô nhiễm do vi sinh vật: Các điềm quan trắc tổng Coliform đều vượt QCVN08:2008/BTNMT- A1 0,7-73,8 lần.
Đoạn sông chảy qua thành phố Buôn $\mathrm{Ma}$ Thuột (từ sau vị trí 3 đến vị trí 9) chất lượng nước bị ô nhiễm hữu cơ, ô nhiễm sinh học đã rất rõ rệt với thông số BOD5 và COD cao gấp nhiều lần so với tiêu chuẩn cho phép trong cột $\mathrm{A} 2$ của QCVN 08:2008. Tại vị trí Mạch Ecôtam thể hiện màu xanh nước biển, tại các vị trí khác chất lượng nước vẫn còn tốt có thể sử dụng cho sinh hoạt. Nước sông có màu vàng tại các vị trí: đoạn sông hạ nguồn sông Krông Nô trước khi nhập thành sông Serepok, suối Ea Druêch vị trí cách điểm xả nước thải của nhà máy xử lý nước thải sinh hoạt thành phố Buôn Ma Thuột 200 m, tại vị 
trí sau Thủy điện Srêpốk 4 và tại sông Serepok vị trí phía sau khu du lịch Biệt Điện - Vườn Quốc ga Yok Dôn (Bến Tha Luống), cho thấy nước có thể sử dụng cho mục đích tưới tiêu và các mục đích tương đương khác. Một số điểm tại vị trí sau Thủy điện Serepok 4, sau KCN Hòa Phú chất lượng nước đã bị ô nhiễm, nước có thể sự dụng cho mục đích tưới tiêu và mục đích tương đương khác, đa số những vùng này người dân chỉ sử dụng nước ngầm và nước máy để làm nước sinh hoạt và ăn uống.

\subsection{Giải pháp phát triển bền vũng tài nguyên nước sông Serepok}

Phát triển bền vững TNN lưu vực Serepok, là khai thác sử dụng nước phải mang lại hiệu quả kinh tế cao góp phần cho phát triển xă hội. Sự phát triển được thiết kế và được quản lý nhằm đáp ứng đầy đủ mục tiêu của xã hội hiện tại và tương lai, trong khi đó vẫn duy trì được tính toàn vẹn về sinh thái, môi trường và thủy văn của chúng. Cần thực hiện một số giải pháp từ Cơ chế chính sách, đến quy hoạch phát triển, vận hành có hiệu quả, nâng cao kiến thức, nhận thức cộng đồng, dội ngữ quản lý và khai thác sử dụng hợp lý nguồn nước.

Xây dựng cơ chế phối hợp quản lý trên toàn lưu vực sông Serepok.

Xây dựng và thực thi các thủ tục Pháp lý cần thiết. Xây dựng cơ chế Hợp tác với Campuchia và Ủy ban sông Me kong về quản lý TNN trên lưu vực.

Xây dựng quy hoạch các nguồn TNN phục vụ cho tưới tiêu, công nghiệp sinh hoạt và cho các nhu cầu khác. Quy hoạch có hiệu quả quản lý tổng hợp TNN lưu vực sông Serepok.

Xây dựng và thực hiện chiến lược xây dựng các các công trình dự trũ, công trình thủy điện, điều tiết và phân phối nước.

Chia sẻ Tài nguyên nước. Xây dựng cơ chế giải quyết công bằng và hợp lý về việc tranh chấp sử dụng nước giữa các tỉnh, huyện...

Xây dựng chiến lược hành động bảo vệ môi trường. Xây dựng và thực hiện hệ thống cấp phép xả thải. áp dụng công nghệ sạch.

Nâng cao nhận thức của cộng đồng, tạo mọi điều kiện thuận lợi nhất cho toàn cộng đồng được tham gia vào công tác quản lý và sử dụng hợp lý Tài nguyên nước trên lưu vực.

Xây dựng đội ngũ quản lý tại địa phương và khai thác các chương trình tài trợ chủa các tổ chức Chính phủ cũng như tổ chức phi chính phú trong nước cũng như ngoài nước.

Chia sẻ thông tin dữ liệu trong lưu vực cũng như quản lý khai thác từ những lưu vực khác, từ trung ương đến địa phương.

\section{Kết luận và kiến nghị}

Kết luận: Phát triển bền vững TNN lưu vực sông Serepok, phân tích nguyên nhân chủ quan, khách quan nhằm phục vụ khai thác hợp lý. Chất lượng nước có sự suy giảm qua các năm, đặc biệt có 3 vị trí có màu đỏ tức là bị ô nhiễm nặng, cụ thể tại vị trí: Km4 suối EaNao tiếp nhận nước thải sinh hoạt Tp. Buôn Ma Thuột, tại những vị trí này nước mặt đã bị ô nhiễm nặng cần có biện pháp xử lý hợp lý, kịp thời. Nước sông có màu vàng tại các vị trí: Cầu 14 sông Serepok, cầu EaNhol, Cầu Krông Nô, nước có thể sử dụng cho mục đích tưới tiêu và các mục đích tương đương khác. Tại các vị trí khác chất lượng nước đáp ứng sử dụng cho sinh hoạt, cụ thể tại vị trí Mạch Ecôtam thể hiện màu xanh nước biển.

So với yêu cầu chất lượng nước cột $\mathrm{A} 2$ của QCVN 08:2008/ BTNMT để làm nguồn cấp nước cho sinh hoạt thì nói chung chất lượng nước lưu vực sông Serepok đều không đảm bảo và đã bị ô nhiễm ở một số đoạn rất rõ rệt. Tuy nhiên mức độ ô nhiễm khác nhau tùy theo ảnh hưởng của các nguồn xả thải.

Đánh giá về ô nhiễm nước lưu vực sông Serepok dựa vào chỉ số WQI đã nêu ở trên phù hợp với kết quả đánh giá chất lượng nước và ô nhiễm nước theo số liệu thực đo chất lượng nước.

Kiến nghị: Để phát triển bền vững tài nguyên nước trên lưu vực sông Serepok cần phải thực hiện đồng bộ một số giải pháp cụ thể từ cơ chế, chính sách đến quy hoạch phát triển, vận hành hiệu quả, nâng cao nhận thức, kiến thức của cộng đồng và đội ngũ quản lý. 


\title{
BÀI BÁO KHOA HỌC
}

\section{Tài liệu tham khảo}

1. Bộ Tài nguyên và môi trường (2011), Sổ tay hướng dẫn tính toán chất lương nước, Quyết định 879/QĐ-TCMT. Hà Nội.

2. Chi cục thống kê Đắk Lắk (2016, 2017, 2018), Niên giám thống kê Đắk Lắk.

3. Huỳnh Phú (2013), Nghiên cứu xây dụng bộ số liệu cho việc ưng dụng mô hình toán mô phỏng diễn biến chất lượng nước sông La Ngà Bình Thuận. Tạp chí Khí tượng Thủy văn, 632, 26-32.

4. Huỳnh Phú (2015), Mô hình toán thủy văn môi trường nghiên cưu chất lượng nước vùng ven biển Trà Vinh. Hội thảo: Nghiên cứu khoa học gắn kết với đào tạo Đại học và Sau đại học tại Trường Đại học Tài nguyên và môi trường Hà nội. NXB Lao động, 184-192.

5. Huỳnh Phú (2018), Tác động của công trình hồ đập tới dòng chảy hạ lưu sông La ngà, Úng dụng mô hình thủy văn thủy lực phục hồi dòng chảy tụ nhiên sau khi có hồ chứa Hàm thuận - Đa $m i$. Tạp chí Khí tượng Thủy văn, 686, 01- 11.

6. Huỳnh Phú, Bùi Xuân Hậu (2016), Nghiên cứu đánh giá và đề xuất các giải pháp phát triển bền vững TNN luu vưc sông Serepok. Trường Đại học công nghiệp TP Hồ Chí Minh.

7. Huỳnh Phú (2019), Nghiên cưu xây dựng phần mềm tin học tính toán chất lương nước WQI cho lưu vục sông Serepok. Tạp chí Khí tượng Thủy văn, 686, 01- 10.

8. Alain, L., (2003), Economic Valuation of Wetlands: an Important Component of Wetland Management Strategies at the River Basin Scale, Document of Ramsar Convention.

9. Haisman, B., (2004), Agriculture and Rural Development Department - World

10. Daniel, S., (1999), Sustainable criteria for water resources development, Washington D.C.

11. Watson, B., (1992), Sustainable and environmentally development of water resoures in Australia. WR series No.75, New York; Yongyi.Y (1992), Policies for sustainable water resoures development in the North China region, Water resoures series No.75, New York.

\section{SUSTAINABLE DEVELOPMENT OF WATER RESOURCES IN THE SEREPOK RIVER BASIN}

\author{
Huynh Phu' \\ ${ }^{1}$ Ho Chi Minh University of Technology
}

\begin{abstract}
Abtract: Water resources are an essential element, closely related to other types of resources such as soil, air and biological resources, which determine the development of a region or territory. Currently, the issue of sustainable management and use of water resources in river basins is an urgent requirement which is of great interest in many parts of the world and Vietnam as a whole. This paper presents the results of studies by various methods, water sampling methods, water quality analysis methods, WQI_Serepok informatics software application method to quickly provide sufficient information regarding water quality, helping management agencies to make appropriate decisions in the management and sustainable development of water resources in the Serepok river basin.
\end{abstract}

Keywords: Development, Sustainable development, Water resources, WQI_Serepok, Serepok river basin. 